\title{
Insecurity the Bane of Development in Nigeria: Echoes from Dramatic Literature
}

\author{
Agatha Njideka Nwanya \\ Department of theatre and cultural studies, nasarawa state university keffi, Nasarawa state
}

\begin{abstract}
Insecurity of lives and properties poses the greatest challenge to development in modern time. Such challenges manifest itself in form of armed robbery, arson, rape, genocide, war, violence and vandalism. In Nigeria, the situation has become worrisome as development indices pointing to ailing Nigerian economy becomes recurring themes and dominant features of many analysts and creative writers. Insecurity has many faces and has assumed an alarming proportion. Apart from ethnic and religious conflicts that afflicted the Nation since 1914 Amalgamation, the nation is currently facing threat of extinction as a result of multiple pressures from insecurity of lives and properties. Despite claims as giant of Africa, Nigerian health and food industries are saturated with adulterated and sub-standard products. This paper examines insecurity as the greatest challenge undermining development in Nigeria from multiple perspectives. The argument in this research sustains that any threat to life and property is a form of insecurity. The central claim is that Nigerian Dramatists expose these security challenges and often proffer solutions. Research shows that high rate of unemployment causes youth restiveness and gross devastation of human and natural resources. The paper concludes that political, health and religious insecurities are the menace of positive development in Nigeria.
\end{abstract}

Key Words: insecurity, development, nigeria, dramatic literature

\section{Introduction}

Insecurity as a term means absence of security. Oxford English Dictionary defined insecurity as a "The state of being open to danger or threat, lack of protection. (Oxford dictionaries.com /definition/English/insecurity). Some scholars have defined security to mean "absence of threat". Nwolise (2012) postulates that security in its natural or original form means "freedom from fear, danger, turmoil, hostility, war and violence". Adedoye (2011) also defined security as "a measure that ensures peaceful coexistence and development at large". It guarantees absence of fears, threats, anxieties, tensions and apprehensions of losing life, liberty, property, goals, values etc, Conversely, insecurity, connotes the presence of danger, hostility and violence in an environment. This working definition is adopted in this research in order to embrace many aspects of insecurity which is often neglected whenever the topic is mentioned. Consequently, the presence of danger and terror in our nation is the utmost concern of this research. On this premise, it is believe that any threat to lives and properties is regarded as insecurity. Insecurity refers to threat to a person's (or groups of People) rights to decent living. It can be seen as an impediment to freedom of movement, association, ownership of properties and so on.

One of the primary duties of any government is to protect fundamental Human Rights of her citizenry as enshrined in her constitution. In Nigeria, the 1999 constitution as amended beams more lights on what constitute Human Rights. A study of 1999 Constitution chapter II and IV enumerates Civil Rights of a citizen to include among others, the following;

(1) Right to security and welfare from government. Section 14(2) a

(2) Right to enjoy national wealth. Section 16(1)(a) (b) (2)

(9)Right to sanctity of Human person. Section 17 (2)b and so on.

These Rights bestowed on individuals are not only to be respected, they are to be guided and protected. For more than two decades now, insecurity of lives and properties has assumed an alarming proportion shattering hopes and aspirations of many people and at the same time tearing families, states and even nations apart. Though the condition is not peculiar to Nigerian Nation, the ugly monster which recently assumed new nomenclature-terrorism, has spread like a wild fire and has consumed many innocent citizens of Nigeria. Insecurity can be found everywhere. From adulterated economic goods especially house hold products such as soap, disinfectants, drugs, creams, fruit drinks to fake automobile products. Increase risk factor of fake products affect health standard of the people. Their continuous presence in the market induces fear on the consumers.

Insecurity of lives and properties include, health insecurity, food insecurity, social insecurity, political and religious insecurity. In Nigeria today, fake and counterfeit drugs remained a constant course for worry to the entire nation prompting the Federal Government to check-mate the increase. It is on record that before the 
advent of Professor Dora Akunyili led National Food and Drug Agency and Control (NAFDAC), Nigerian drug market was saturated with fakes and counterfeits drugs. Drugs like pain relief tablets such as paracetamol, injections and anti-biotic are "manufactured" and distributed in every nooks and crannies at Bridge Head Market Onitsha, Aba and Kano. Till date, the situation has slightly improved. Closely related to this is an abuse of hard drugs. Consumption of Hard Drugs is on the increase. In the year 2010, United Nations Organisation for Drugs and Crime (UNODC) gave the figure as 5\% of the world adult population representing about 230million people. See (www.org/documents/data-and-analysis/WDR2012/WDR_2012_web-small.pdf). Statistics shows that Nigeria is topping the list in African continent. On the NAFDAC website, illicit drugs and fake products deals read like "Riot Act" thus:

(a) Man Arrested with \#106m fake condoms and drugs 10 May, 2013

(b) NDLEA nabs man with 1.8bn worth of Hard Drugs 7 April, 2013

(c) NAFDAC impounds fake baby Drinks 4 April 2013

(d) NDLEA destroys 13.6m worth of Hard Drugs 17 November 2012

(e) Two Nigerians arrested with drugs worth $\$ 33.300$ in Bangkok 19 Oct 2012.

(See www.gistmania.com/talk/topics 152370. O.html.) It is even more worrisome that many youths today consume these narcotics openly in the streets while the security agents look the other sides.

Close to this upsurge is quaky in the health sector. Health personnel constitute insecurity of the highest order in Nigeria. Today there are many non- professionals masquerading as trained medical experts. Many native doctors, herbalists, occultists, necromancers today deceive Nigerian masses with claims that they are trained and qualified health personnel. Nigerian media directly or indirectly promote these fake medical practitioners. For instance, Nwanya (744-745) noted with dismay that Federal Radio Coporation of Nigeria (FRCN) 102.5 Awka, devoted more air time advertising herbal medicine. A situation which promotes "business boom" for all quackery in Awka metropolis and Anambra environs. According to her, "the air time devouted for sale of herbal medicine leave one in doubt that the practitioners are the owners of the station or that the station cannot survive the financial burden and cost of operation without their patronage". A case was also reported on the nation's media on an abuse of Human Right through sharp practices of fake medical personnel. We heard over the radio how foreign nationals float fake hospitals in Nigeria. In one of the so called Hospitals run by quake Indian Surgeons with fake certificates, a woman with an acute case of fibroid was their victim. Not only that they opened up on the woman and stitched back, they also parted away with a woeful sum of five hundred thousand naira. Such an unfortunate sharp practice induces fear and tension on an average citizens and cast doubt in people's mind on competency of some medical professionals. Obviously, the Indian mercenaries are quite aware of predicaments of average Nigerian fibroid patience who shuttles Indian hospital monthly for treatment. There is no gainsaying that Nigeria hospitals are death traps and major obstacle to development. Apart from exploitation of patients and their relatives, there seems to be a conspiracy of some sort. Medical experts are often absent from duty in General and Teaching hospitals. Consultants and resident doctors leave their jobs for House Officers and even Youth Corp Doctors. For a patient to see a medical professional at the point of emergency is like a proverbial Carmel passing through the eye of a needle. Fear, terror and threat to life are common features in most Nigerian hospitals.

Food insecurity is another big challenge hampering development. It is often said that a healthy nation is a happy nation. Nigeria nation cannot guarantee the quality of what her citizens eat as food, fruits, vegetables, drinks, or even water. Most consumables in the markets are not suitability for consumption. Food insecurity also steers Nigerians in the face. Apart from its inadequacy, food preservation and preparation pose a big health threat to the masses. Consumption of fake and polluted food items and drinks are responsible for soaring health problems. Food, fruits and other consumables are adulterated at random by traders and sometimes by quake manufacturers. Chemicals such as magnesium bromides and carbides are often used to preserve or improve the quality and quantity of bread and fruits like bananas, pawpaw, mangoes and oranges. Red oil is often mixed with colorings. Even local delicacies such as "okpa Igba", "Ukpaka" etc are not left out. No wonder terminal diseases such as cancer, diabetis mellitus, stroke, kidney and heart failure are on the increase. It is no longer news that sub-standard goods found their way into Nigerian markets.

Apart from the above problems, social and political insecurity have been on the increase. Social insecurity includes both infrastructures and security of life. Recently, Nigerian has joined the comity of terrorist Nations on account of mayhem and wanton destruction of lives and properties by a religious group known as Boko Haram. This group continuously bomb public places especially in the Northern part of Nigeria killing thousands upon thousands of innocent civilians in the province. The climax of the activities of the sect/terrorists was the kidnapping, raping and hostage keeping of innocent school girls numbering about two hundred and fifty (250) at Chibok in Madugiri, Unfortunately, before the emergence of Boko Haram in 2009, ethnic militia in Niger Delta Regions took the centre stage. Movement for the Survival of Ogoni People (MOSOP). The Egbusi 
Boys, Niger Delta People's Volunteer Force (NDPVF) all declared war against the nation causing social mishaps.

Poor and inadequate social infrastructure makes meaningful development difficult. Nigerian power sector is gradually grounding to a halt. As the world move away from the use of the conventional generating stations that encourages environmental pollution through carbon iv oxide (Co2) emission, Nigeria remains a dumping ground for all kinds of re-furbished generators from Asia countries. Many companies and corporate intuitions have been frustrated out of business as a result of inadequate and erratic power supply. Incidences of fire out-break left many casualties. There is a serious dearth of social infrastructures in the country and where they exist at all, they are grossly inadequate. Road networks and (recently the Airways) are dead traps for their users. High ways, for instance are rippled with double insecurity problems. Either the road users are trapped with poor road condition or they are faced with dare-devil armed robbers ready to snip off their lives in a second. Plying Nigerian roads is a mirage. Victims of road mishaps are many. They are like J.P. Clark's "funeral Piles at home eating up the forest" ("The Casualties"). This writer became a victim in September 2012 at Kubua, along Nyanya Abuja road. A tipper driver lost control of his vehicle as a result of brake failure on a traffic jam and smashed an eighteen-Setter commercial bus killing two passengers and left the writer with a fracture on her left humerus. In the midst of all these challenges, what are the contributions of Dramatic Literature? How does dramatic Literature address these challenges?

\section{Dramatic Literature: A Window On Nigerian Insecurity}

Research in this area shows that Dramatic Literature written in Nigeria traces the upsurge in political violence, pipe-line vandalisation, arson, kidnapping, rape, murder and other crimes to activities of ethnic militias in Niger-Delta Regions. Irobi (1989), (Okumagba (2009), Darah (2010) share these view. The bulk of these works also laid blames of terrorism on the door steps of Niger Delta Militants. In studying the bulk of these Literatures, the overall scenarios loom with the images of exploitation, subjugation, poverty, denial, frustration and misery. The masses are faced with excruciating circumstances marred with total collapse of a social system. Studies indicate that the people of the Region are intimidated, suppressed, humiliated and denied their fundamental human rights-right for decent living. All the early approaches to the study mentioned above adduce the same argument. These facts are presented in bizarre manner by playwrights, Esiaba Irobi, in his Hangmen also Die (1987) Ahmed Yerima's Hard Ground (2006), Emma Dandaura's Venom For Venom (2010) J.P Clark' The Wives Revolt (1991) and All For Oil (2000). The common characteristic of all the characters presented in the texts with exception of J.P Clark's (The Wives Revolt) is youth restiveness. Able-bodied youths who are graduates and unemployed perpetuate violence and vandalism. They form gangs and continue to terrorise the people. Kuru, a character in Yerima's Little Drops explains that war is all it takes to gain freedom especially, economic freedom.(52) The insecurity problem and youth insurgency in the region are by product of unemployment. Irobi and Dandaura capture the situation in a most pathetic mood thus: In Dandaura's Venom For Venom

Youth 5 Just look at me.! I graduated with first class honours degree in petro-

Chemical Engineering.Tega, are you not a Master Degree Holder in

Enviromental Management? There are also among us here a $\mathrm{PhD}$

holders in Remote Sensing Electrical Engineering (17)

When you examine this statement alongside the claims of Irobi's youths, then you will appreciate why Africa as a continent remain underdeveloped. All the early approaches to the study of African Underdevelopment such as Walter Rodney's How Europe Underdeveloped Africa and Frantz Fanon's The wretched of the Earth blamed African Underdevelopment on population loss. Rodney (110) argues that slave trade which encouraged deportation of able -bodied African youths; ages 15-35 in Europe and America affected the size of African population especially the African Labour force. Today, the scenario has changed. What we have is the opposite - a situation where African leaders themselves lack foresight and deliberately marginalise their youths and rupture their future. From Hangmen Also Die, Irobi paints the picture of a devastating youths soaked deep in bloodletting because they want to revenge on the society that ruptured their future. The characters in the drama, Mortuary, Dayan, Tetanus etc declared their credentials thus:

MORTUARY... I hold a First Class Degree in Statistics

and have been unemployed for the past six years.

DAYAN...I have a Masters Degree in Political Science.

TERTANUS ...A fully qualified Mechanical Engineer. I have

have been unemployed for seven years. (34) 
Today, the problem is not just that the youths are unemployed, but graduate youths and the country's active work force. Dr Yemi Kale, Chief Executive officer of Nigeria Bureau of statistics (NBS) was quoted to have said that unemployment was highest among youths aged between 15and 24, 25-44. In advanced counties, youths are encouraged through incentives in order to achieve maximum productivity. They are not left to roam the street and form gangs and terrorists. There are adequate provisions to enable them realize their dreams. But in Africa, particularly here in Nigeria, we have failed to plan adequately and now we are reaping the fruits of our failure. Esiaba Irobi, Emma Dandaura and J.P Clark interrogate the wastages of lives and properties in Niger Delta region. The environmental hazards affect both aquatic livestock and human being. Irobi presents this in pathetic way with the story of Ibiaye the fisherman. He lost his sons, properties and finally his sight to oil pollution in the creek. The only thing the multi-billion oil companies did was to offer a stipend as compensation to the people of the area. Unfortunately Chief Erekosima, the greedy politician, steals the three million naira which he lavishes on expensive chieftaincy title. (Phase5). Similar scenario is also painted by Dandaura's King who uses a member of his cabinet, Elder Eriri to siphon compensation money paid to his community by the Oil Companies operating in their communities. The watchful eyes of the youths caught him with a sum of 1.5 billion naira. (Scene 3: 15). The women in J.P Clark's The Wives Revolt, are denied a fair share of the oil money. The deduction from the gloomy pictures painted above lay credence to Irobi's belief that "there is a thief in all of us" (42). This philosophy runs through the plays and implicates the activities of Multi- National Oil Companies represented by Shell B.P, Texaco, Gulf, Elf, National and Total. In the first instance, these companies failed woefully to fulfill their agreement and promises to the people.

In 1999, the greatest African playwright, philosopher and critic of Theatre, Professor Wole Soyinka wrote a dramatic piece, Beatification of the Area Boy which Emmanuel Uzoji believes is the prophetic fulfillment of 20007 General Election in Nigeria. The guru himself warns on massive unemployment of Nigerian youths and its social and political implications. Uzoji (56), writing on the topic "The Prophetic Power of drama: Nigerian's Election and Soyinka's Beatification of the Area Boy", argues that " no nation can lay claims to sanity without order and the law enables such order". Insecurity, we know is a grandson of lawlessness. And when there is a total breakdown of law and order, the masses are terrorized, maimed and traumatized. From the texts, the tap root of underdevelopment is visible. The militant boys enraged with government failure to address their problems blew up oil pipelines and refineries. A condition that prompted Soyinka to remark in Beatification of the Area Boy that "the nation has lost its soul" (10). Unemployment and poverty are twin sisters. Both carry a kind of stigma that dulls the senses and makes one becomes monumentally mad.

Dramatic Literature also illustrates that poverty and insecurity are the bane of Nigerian development. Poverty in Nigeria is a reality and the security challenges discussed, further aggravated the problem. African duel experiences of slavery and colonialism and recently, criminal activities of Multinationals Oil companies and federal government impoverished the masses. Both government and expatriates scramble for land from the natives. In most cases, these land owners are never compensated. Land issues in Africa also raised the question of identity. When people are displaced from their land, they move to a safer habitation where they become tenants. And we know that class stratifications are basis for social structure. This issue of identity also generates conflicts among the characters in Dandaura's Venom for Venom, Elder Igbinedion quickly reminds Elder Briggs that his great-great grandfather was a fugitive who was banished from Idololand (8). Identity crisis rock Africans irrespective of wherever they reside. Even people of the same culture are not left out. For instance despite the influence of Christianity the Igbo people of Nigeria, "Osu cast"(ie Outcast system) still exist in some quarters. Not even Christianity has helped the matter. The constant rivalry and rancor between the Roman Catholics and the Protestant Christians is worse than the practice of Osu cast system. This researcher believes that Nigeria cannot make meaningful progress unless she improves on her Human Right records and protects the rights of her citizens irrespective of one's religious or ethnic affiliation.

Armed robbery, and recently, kidnapping are another faces of insecurity that have proved very devastating to the nation's economy. The surging nature of armed robbery attack on the high ways, at home and even in offices call for sober reflection. It has become so rampant that it is gradually become a culture. Femi Osofisan aptly captures this in his drama, Aringindin and the Nightwatchmen. Armed robbers burgled a business premise three times in two weeks and swept the entire stores leaving the owners in perpetual agony. From the Kansilor, we understand that the Baale of the community is playing politics with people's lives and properties. Like a typical Nigerian leader, Baale is interested in the prescription of the oracle. And for kansilor the big question is on security of life and property.

KANSILOR I am talking of a simple question of people's

property. Baale! Of their right to go to bed

and expect to rise the following morning

without grief! (134) 
Judging from the attitude of the people therefore, one could see frustrated, maimed and harassed masses. Unfortunately, as the chief security officer of the community, Baale has no solution to the problem. Similarly in the country, such important security challenge is often swept under the carpet by Nigerian security agents. That is why the people burst out laughing when Baale suggests reporting the case to the police. Frustrated Nigerian masses also do little to prevent crime. In most cases crime is not given the seriousness it deserves. In Osofisan's drama, Nigerian police force is a symbol of corruption and oppression as such, commands little or no respect among the people. Despite the fact that Lamidi, the night watchman is shoot dead by the robbers, the sympathizers are laughing and entertaining themselves. Again, Kansilor scolds them for their callousness.

KANSILOR.... A man is dead, others are ruined, the town is in panic, but here you are, dancing! Dancing...(134)

From the forgoing, it is obvious the reason for so much insecurity in the land is poverty. It is believed that eighty percent of Nigerians are wallowing in abject poverty. The staggering un-employment rate of $23.9 \%$ contributes in no so measure in sustaining the culture of poverty. Domestication of poverty persist in Africa because the colonialist and their big time business merchants such as multinational oil companies tactfully displaced the natives from their traditional occupations such as fishing, farming, hunting, handcrafts as well as indigenous technology like blacksmithing and "introduced them to the world of material poverty." (Chukwuemeka 194). Poverty is a reality in Nigeria.

Insecurity has also led to violence against women and Children. Outright abuse of human dignity has become the order of the day. Rape as a violent crime is on the increase and many women are helpless victims. In dramatic Literature, Victor Dugga and Ahmed Yerima present innocent women as victims. In Dugga's Hope Harvesters, Nkoyo works with KickAction Courier and in her bid to deliver a parcel in a rugged neighborhood; a gang of area boys waylaid her, took her to an uncompleted building and raped her (28-29). Mukume in Yerima's Little Drops is highly traumatized as a result of rape. Hear her defense;

Mukume ...Please, I have been raped three times today already.

Kill me instead. Shoot me and let me die! I will not

let another man touch me. Kill me instead. (10)

These are fictions from dramatic Literature you may say, but many such stories also adore the pages of Nigerian Newspapers. Sun Newspapers of Sunday, July 10'2013 carried a report title "Neighbours from hell: Gang...rape disabled pregnant victim" Again in Vanguard Newspapers of Wednesday, July, 24.2013, Daud Olatunji reports that Ogun State Police command has arrested a 45- year old man, Toyin Sodimu, for allegedly raping his own 16 year old daughter. Female gender is facing psychological trauma as a result of insecurity in the country. Presently, Nigerians are yet to come to grip on the fate of Chibok girls who are being raped repeatedly by members of Boko Haram religious terrorists.

\section{Insecurity And Development: The Contentions Issues}

Development in human society according to Rodney (1) is a many-sided process. At the level of individual, it implies increased skill, and capacity, greater freedom, creativity, self discipline, responsibility and material well-being. Apparently, this is lacking in Nigeria situation. He argues further that development means a capacity for self sustaining growth. It means that the economy must register advances which in turn will promote further progress. Again, while develop countries of the world sustain their development strategies through viable investment in trade and commerce as well as sound developed technology, Africans tootle at the back. In the 70s and 80s we used to hear about Aba made products in Nigeria. Today, Aba producers have abandoned their small scale production of goods as a result of "dumping" in Nigerian Markets. Some are still in a state of inertia with inadequate funding from government to sustain their trade. Northern textiles have grown morbid and the Groundnut pyramid is now, history. It seems to me that Nigerian nation thrives on negation. Apparent hatred, jealousy, greed are often demonstrated on issues that are common course. Emphasis is always on run him down syndrome.

Development according to Akaaer and Asen is

A continuous process of harnessing all available human and material resources of a society in a way that it is compatible with the final goal of achieving a quality of living standard that is based on satisfaction, justice, equality, liberty, happiness, freedom and progress.(228) 
The above definition calls to mind two important variables in discussion of development. That is: harnessing available human and material resources. There is no doubt the nation has continuously harness human and material resources but the problems seem to rest on equitable distribution of these resources to pave way for progress and happiness. Frantz fanon in his book, The Wretched of the Earth remarked that "what counts today, the question which is looming in the horizon, is the need for a redistribution of wealth. Humanity must reply to this question or be shaken to pieces by it." (78) Of course where there is equity, there is peace and there is progress. But the bogging question is: Is there equity in our nation today? If yes, then why are Nigerian youths unemployed? They constitute the active work force. Yet, they are treated like foreigners in their own country. National Bureau of Statistics (NBS) put the figure of unemployed Nigerians in the first half of the year at $23.9 \%$. It rose up from $21.1 \%$ in 2010 and $19.7 \%$ in 2009 . The data specified that unemployment level rose from more than 12million in 2010 to more than 14 million in 2011 with the figure increasing by1.8million between December 2010 and June 2011. Dr Yemi Kale, the boss of NBS noted that unemployment was highest among Nigerian youths. According to him, $56.3 \%$ of active population from the figure represents active population of 84 million people in the labour force which stood at 61.5 million, implying that 22.5 million are not working. (www.nairaland.com?805178/unemployment-rate-nigeria-hits-23.9) In order words, one third of the active force is not working. How can such economy develop? Until Nigeria and Africa in general address squarely the problem of youth unemployment, the continent will never know peace. When the youths are not meaningfully engaged, they dissipate their energy in wrong direction. Equitable distribution of resources is the answer.

Finally, insecurity of lives and properties persists because the nation's policy is being colonized by a few political cabals. Nwanya and Chikada (537) noted that politicians "display absolute ignorance in matters that affect the masses and rather expedite energy in frivolities. The leaders are not helping matters at all. Thy skifully perpetuate youth unemployment and during political campaigns they become a readymade weapon for them. It is only at that period that politicians suddenly remember that the youths of this nation should be equipped. And what kind of equipment do they get? - AK 47 raffles and machetes to deal with their perceived political opponents. In order words, the only job for teeming Nigerian youths is thuggery. Some of these youths after election join Arm robbery gangs, kidnappers and sometimes militants groups especially when they realized that their godfathers brainwashed them with empty promises.

\section{Conclusion}

This paper has advanced the evidence, which indicate that insecurity of lives and properties is a bane on Nigerian economy. Several evidences are provided in this research suggesting that insecurity of lives and properties is high. Consequently, wanton destruction of lives and properties has continued unabated as a result of poverty and excruciating hardship the masses are subjected to in their daily lives. The data collected and analysed indicated a serious manipulation of every aspects of Nigerian life and culture. Dramatic Literature as a window in Nigerian society explores the dangers that insecurity poses on the nation. Environmental degradation is the greatest problem in Niger-Delta regions. Gas flaring and pipeline vandalisation pollute the environment and further worsens dilapidation of ozone layers. These pose serious threat to terrestrial and aquatic habitats. The dramatics blamed Niger Delta youth restiveness on unemployment and the expatriates who connive with local chiefs in order to short changed the masses. These multinational oil companies together with their local collaborators continue to siphon the people's wealth. The youths are up in arms because they have no future as such they resist neo-colonialism through brute force.

Finally, with high level of insecurity as the bedrock of Nigeria society, positive growth and development remain a mirage to the nation.

[1]. Clark, J.P. All for Oil. Lagos: Malthouse Press. 2000.

[2]. ... "The Casualties". A Selection of African Poetry. Senanu, K.E and Vincent T. (ed)

[3]. Longman $1976(136-137)$

[4]. ... The Wives' Revolt. Ibadan: Univesity Press, 1991.

[5]. Chukuemeka, Amaefula Rowland. "Multinational Corporation and Retrograding Development in Nigeria: A study of HenrryBelgam's The Hidden Treasures in Nigerian literatures" in Structural Adjustment, policy and Globalisation. Proceedings of the International on Nigerian Literature. Gombe State University (2010) 1991-198

[6]. Darah, GG. "Struggle for Oil in the Niger Delta" in Nigerian Literatutre Today Journal of

[7]. Contemporary Nigerian Writing. Onukaogu, A.B and Onyerionwu.E. (ed). Ibadan: Craft Books. Inaugral Edition: First Quarter March 2010 (no) 117-182.

[8]. Dandaura, Emmanuel Samu. Venom for Venom. Lagos: Dat and Partners Logistics. 2010.

[9]. Dugga, S.Victor. Hope Harvesters. Lagos: Dat and Partners. 2008.

[10]. Fanon, Frantz. The Wretched of the Earth. England: Penguin Books Ltd.(1990) 1-255

[11]. Irobi Esiaba, The Hangemen Also Die. Enugu: ABIC Publisher, 1989.

[12]. Nwanya, Njideka Agatha. " FRCN 102.5 FM,Awka Advertisment of Health Programmes: Implication for Sustainable Development". The Humanities and Sustainable Development. A.B.C Chiegboka etal (edt) Nimo: Rex Charles and Patrick, (2011) 742-749. 
[13]. Nwanya, A.N and Chikada, D. "Satire, Antidote to Good Governance: The exegesis of Two Nigrian Dramatists". The Humanities and good Governance. A.B.C. Chiegboka etal (edt) Nimo: Rex Charles and Patrick (2012) 533-542

[14]. Okumagba, Paul. "Ethnic Militias and Criminality in Niger Delta" African Research, Review: An International Multi-Disciplinary Journal. Ethiopia: Vol.33. (April, 2009) 315-330.

[15]. Osofisan, Femi. Arigindin and the Nightwatchmen in Major Plays 2 by Femi Osofisan. Ibadan: Concept Publishers. 2003 (123-199)

[16]. Rodney, Walter. How Europe Under developed Africa. Abuja: Panaf Publishing Inc 1972.

[17]. Uzoji, E "The Prophetic Power of Drama: Nigerian's Elections and Soyinka's Beatification of Area Boy" Nigerian Theatre Journal. A Journal of the Society of Nigerian Theatre Artists (SONTA) Tor Iorapuu (ed) Vol.11 no 1 - 2011 (56-61)

[18]. Soyinka, Wole. The Beatification of Area Boy. Ibadan:Spectrum Books 1999

[19]. Yerima, Ahmed. Hard Ground. Ibadan: Kraft Books. 2006

[20]. Yerima, Ahmed. Little Drops. Ibadan: Kraft Books. 2009

[21]. Oxford Dictionaries .com/definition/English/insecurity 8 June, $201311.02 \mathrm{am}$

[22]. ww.unodc.Org/documents/data-and-analysis/WDR2012/WDR_2012_web-small.pdf 13 June, 2013.6.01pm.

[23]. www.nairaland.com/805178/unemployment-rate-nigeria-hits-23.9 13 June, $20136.35 \mathrm{pm}$

[24]. www.gistmania.com/talk/topic,152370.0.html. 16 June, $20134.15 \mathrm{pm}$ 